\title{
Value addition of low fat chicken sausage with rice and wheat flour M Rokib ${ }^{1}$, M Habib ${ }^{2}$, MA Hashem ${ }^{3}$ and MS Ali ${ }^{1}$
}

${ }^{1}$ Department of Poultry Science, Bangladesh Agricultural University, Mymensingh, 2202; ${ }^{2}$ Graduate Training Institute, Bangladesh Agricultural University, Mymensingh, 2202; ${ }^{3}$ Department of Animal Science, Bangladesh Agricultural University, Mymensingh, 2202

\begin{abstract}
The study was conducted to evaluate the effect of rice and wheat flours on low fat chicken sausages. Sausages were prepared into three different groups: control; broiler breast meat sausage without any flour $\left(T_{1}\right)$, sausage with addition of $10 \%$ rice flour $\left(T_{2}\right) \& 10 \%$ wheat flour $\left(T_{3}\right)$. All parameters were analyzed at $0,15^{\text {th }}$ and $30^{\text {th }}$ days of storage period. The proximate compositions of different sausages were analyzed and highly significant $(p<0.01)$ differences were found in DM $(\%)$ and CP $(\%)$. Significantly $(\mathrm{p}<0.01)$ lower DM $(\%)$ and higher CP $(\%)$ was found in $\mathrm{T}_{1}$. Both DM $(\%)$ and CP $(\%)$ content were increased with increase of storage time. The storage period have significant $(p<0.01)$ effect on different biochemical (FFA, POV and TBARS value) and microbial (TVC, TCC and TYMC) test. In both cases the values were increased with increase of storage period. Different types of sausage and storage period have an effect on redness $\left(a^{*}\right)$ value. In sensory analysis, significantly lower flavor, juiciness and tenderness were found in $T_{1}$. Although flavzAQAor, juiciness and tenderness were varied during sensory evaluation, overall acceptability did not differ among the three treatments. Results of this study revealed that low fat chicken sausages can be made with $10 \%$ rice and wheat flour without lowering the overall acceptability.
\end{abstract}

Key words: rice flour, wheat flour, breast meat, sausage, overall acceptability

Bang. J. Anim. Sci. 2019. 48 (2):99-107

\section{Introduction}

Chicken meat is considered a highly nutritious food because it contains relatively high protein and low-fat percentages as well as vitamins and minerals (Jung et al., 2015). In addition, it has fewer religious restrictions as compared with pork and beef. Among different meat products, chicken sausage is gaining popularity in many countries of the world. Particular attention has focused on health problems associated with fat content in food, and consumers are looking for no-fat or low-fat meat products (Miller and Groziak, 1996). To minimize the fat level from dietary food items, chicken breast sausage is thought to be a healthful food because of its lowfat content and high protein content (Ali et al., 2011). Carbohydrate-based fat substitutes use plant polysaccharides such as fibers and starches to retain moisture and to provide textural qualities that usually provided by fat (WylieRosett, 2002). Yang et al. (2009) reported that the total substitution of fat in duck sausages by rice flour produce a more acceptable product.
Rice has shown promise for increasing yield and juice retention in meat (Huang et al., 2005), but limited research was done with rice compare to other cereals to produce meat product. According to Laureys(Laureys,1996), rice flour can be used as processing aids, ingredients in health food, expanding agents in extrusion food, flavour carriers, emulsifiers and fat replacers in food products. It is also true to wheat where limited research was done with wheat compare to other cereals to produce meat product. Duck sausages made with wheat flour had higher protein content and lightness value and a harder texture. Gnanasambnadam and Zayas (1992) showed that addition of wheat flour to Frankfurter sausage increase WHC, decreased cooking loss, improved viscosity, cohesiveness, better stability. However, low fat chicken sausages value added with different types of cereal flour product does not get enough attention by the researcher. The present study was undertaken to find out the effect of addition of rice and wheat flour on the quality properties of low fat chicken sausages and to compare the effectiveness of incorporated rice and wheat flour on sausages prepared with different types of cereal flour. 


\section{Materials and Methods}

The experiment was performed in the laboratory of the Department of Poultry Science and Department of Animal Science in Bangladesh Agricultural University (BAU), Mymensingh, Bangladesh. The live Broiler was purchased from BAU Poultry Farm, and rice and wheat flours were purchased from Kamal Ranjit (K.R) market, BAU, Mymensingh. The broilers were slaughtered; breast meat was collected and transferred immediately stored frozen at $-20^{\circ} \mathrm{C}$ in "Poultry Science Laboratory". Garlic, onion, ginger, meat spices, salt, and sugar were purchased from local market.

Table 1: Sausage formulation for all treatment

\begin{tabular}{|c|c|c|c|}
\hline \multirow[t]{2}{*}{ Ingredients $(\mathbf{g})$} & \multicolumn{3}{|c|}{ Different treatments } \\
\hline & $\begin{array}{l}\text { Broiler } \\
\text { sausage } \\
\left(\mathbf{T}_{\mathbf{1}}\right)\end{array}$ & $\begin{array}{l}\text { Sausage } \\
\text { from } \\
\text { broiler } \\
\text { and } \\
10 \% \\
\text { rice } \\
\text { flour } \\
\left(\mathbf{T}_{\mathbf{2}}\right)\end{array}$ & $\begin{array}{l}\text { Sausag } \\
\text { e from } \\
\text { broiler } \\
\& 10 \% \\
\text { wheat } \\
\text { flour } \\
\left(\mathbf{T}_{3}\right)\end{array}$ \\
\hline Breast meat $(\mathrm{g})$ & 1000 & 900 & 900 \\
\hline Flours (g) & 0 & 100 & 100 \\
\hline Salt $(g)$ & 15 & 15 & 15 \\
\hline $\begin{array}{l}\text { Sodium } \\
\text { tripolyphosphate } \\
\text { (g) }\end{array}$ & 3.3 & 3.3 & 3.3 \\
\hline $\begin{array}{l}\text { Sodium } \\
\text { erthorbate }(g)\end{array}$ & 0.37 & 0.37 & 0.37 \\
\hline Maltodextrin (g) & 14.8 & 14.8 & 14.8 \\
\hline $\begin{array}{l}\text { Spice/ seasoning } \\
\text { (g) }\end{array}$ & 3.7 & 3.7 & 3.7 \\
\hline
\end{tabular}

\section{Chicken Sausage Preparation}

All visible fat and connective tissue were trimmed off as far as possible with the help of knife and the meat was cut into small pieces. Chicken breast meat was grinded with the help of meat grinder. The grinded meat was then mixed with some spices. Minced meat was chopped in bowl chopper along with salt, Sodium tripolyphosphate, Sodium erthorbate and Maltodextrin. The meat was divided into 3 parts. $\mathrm{T}_{2}$ and $\mathrm{T}_{3}$ were then compounded with $10 \%$ ( wt. /wt.) Rice flour and wheat flour respectively. Meat from each mixture then taken and were wrapped with small square pieces of plastic as a casing in to candy like structure. One batch of control sausages was also prepared using only broiler meat. The prepared sausages were then packed in poly ethylene bags and stored refrigerated for up to 30 days and assessed immediately after processing ( 0 day) and at an interval of 15 - and 30-days post storage.

\section{Product analysis}

\section{Proximate analysis}

Proximate composition of sausage such as Dry Matter (DM), Ether Extract (EE), Crude Protein (CP) and Ash were carried out according to the methods of AOAC (2005). All determination was done in triplicate and the mean value was reported.

\section{Color analysis}

The surface color (CIE $L^{*}, a^{*}, b^{*}$ ) of breast meat sausage samples were measured at the department of Food Science and Technology using a Minolta Chroma meter (Minolta CR 410, Tokyo, Japan) standardized with a white plate $(Y$ =93.5, $X=0.3132, y=0.3198)$. Three random reading were taken from each sausage sample.

\section{Physicochemical analysis}

To determine cooking loss, weighed $10 \pm 1 \mathrm{~g}$ sample, wrapped in a heat stable foil paper and kept in water bath at $75^{\circ} \mathrm{C}$ for $30 \mathrm{~min}$. Samples surface are dried and weighed. Cooking loss was calculated as the percentage of the loss weight of the cooked sample (Symeon et al., 2010). Again, 5 grams of the sausage sample were placed in a blender jar and $50 \mathrm{ml}$ of distilled water were added. The mixture was blended at high speed for $1 \mathrm{~min}$. The ph of the mixture was measured using a digital ph meter.

\section{Biochemical analysis}

There were three types of biochemical analysis viz. Free Fatty Acid Value, Peroxide Value and Thiobarbituric Acid value. FFA value was determined according to Rukunudin et al. (1998). POV values of the sausage samples were determined according to AOAC (1995). Lipid oxidation was assessed in triplicate using the 2thiobarbituric acid (TBA) method described by Schmedes and Holmer (1989).

\section{Microbial assessment}

In microbial assessment total viable count, total coliform count and total yeast -mold count was undertaken. A quantity of $10 \mathrm{~g}$ of sausage sample was aseptically excised from stored stock sample. Each of the stored sausage samples was thoroughly and uniformly macerated in a mechanical blender using sterile diluents $(0.1 \%$ peptone water) as per recommendation of International Organization for Standardization (ISO, 1995). A quantity often (10) gram of the 
sausage sample was taken aseptically transferred into a sterile container containing $90 \mathrm{ml}$ of $0.1 \%$ peptone water. A homogenized suspension was made in a sterile blender. Thus 1:10 dilutions of the samples were obtained. Later on, using whirly mixture machine different serial dilutions ranging from 10-2 to10-6 were prepared according to the standard method (ISO, 1995). The media employed for the bacteriological analysis included plate count agar (PCA), MacConkey agar (MA) and potato dextrose agar (PDA).

\section{Sensory evaluation}

Different sensory attributes were examined at 1 day old sausage. Each sausage sample was evaluated by a trained panel of 6-honorable judges at Bangladesh Agricultural University. Recruitment, selection and training of panelist were performed according to sensory evaluation procedure (AMSA, 1995), 6 panelists were screened from 10 potential panelists using basic taste identification test. The sensory questionnaires measured intensity on a 5-point balanced semantic scale (weak to strong) for the following attributes color, smell, tenderness, juiciness and overall acceptability. Sensory evaluation was carried out in individual booths under controlled conditions of light, temperature and humidity. Sensory qualities of the samples were evaluated after cook on day one.

\section{Statistical analysis}

The cooking loss (\%) of sausage batter and the sensory data from different sausages were analyzed using analysis of variance technique by a computer using SAS statistical package program in accordance with the principles of Completely Randomized Design (SAS, 2009). DMRT was done to compare variations among treatments where ANOVA showed significant differences. While the proximate, physicochemical and microbial data from different sausages were analyzed with $3 \times 3$ factorial design (where 3 are different sausages and 3 are different storage periods) with the principles of Completely Randomized Design (SAS, 2009).

Table 2: Proximate composition of low fat broiler meat sausages incorporate with rice and wheat flour during different storage time

\begin{tabular}{|c|c|c|c|c|c|c|c|c|}
\hline \multirow{2}{*}{$\begin{array}{l}\text { Param } \\
\text { eter }\end{array}$} & \multirow{2}{*}{$\begin{array}{l}\text { Storage } \\
\text { time (D) }\end{array}$} & \multicolumn{4}{|c|}{ Treatments ( $\mathrm{T}$ ) } & \multicolumn{3}{|c|}{ Level of Significance } \\
\hline & & $\begin{array}{l}\text { Broiler } \\
\text { meat }\left(T_{1}\right)\end{array}$ & $\begin{array}{l}\text { Broiler } \\
\text { meat }+10 \% \\
\text { rice flour }\left(T_{2}\right)\end{array}$ & $\begin{array}{l}\text { Broiler } \\
\text { meat+10\% } \\
\text { wheat } \\
\text { flour }\left(T_{3}\right)\end{array}$ & Mean & $\mathbf{T}$ & D & $\mathbf{T} * \mathbf{D}$ \\
\hline \multirow{4}{*}{$\begin{array}{l}\text { DM } \\
(\%)\end{array}$} & 0 & $28.87 \pm 0.11$ & $30.10 \pm 0.10$ & $28.92 \pm 0.14$ & $29.30^{c}$ & \multirow{4}{*}{ ** } & \multirow{4}{*}{$* *$} & \multirow{4}{*}{ NS } \\
\hline & 15 & $29.05 \pm 0.03$ & $30.15 \pm 0.09$ & $29.48 \pm 0.08$ & $29.56^{\mathrm{b}}$ & & & \\
\hline & 30 & $29.53 \pm 0.07$ & $30.75 \pm 0.19$ & $29.93 \pm 0.05$ & $30.07^{\mathrm{a}}$ & & & \\
\hline & Mean & $29.15^{c}$ & $30.33^{a}$ & $29.44^{\mathrm{b}}$ & & & & \\
\hline \multirow{4}{*}{$\begin{array}{l}\text { CP } \\
(\%)\end{array}$} & 0 & $23.25 \pm 0.35$ & $20.11 \pm 0.26$ & $21.40 \pm 0.12$ & $21.59^{b}$ & \multirow{4}{*}{ ** } & \multirow{4}{*}{$* *$} & \multirow{4}{*}{ NS } \\
\hline & 15 & $23.52 \pm 0.39$ & $20.33 \pm 0.15$ & $21.68 \pm 0.05$ & $21.84^{\mathrm{b}}$ & & & \\
\hline & 30 & $24.75 \pm 0.35$ & $21.57 \pm 0.27$ & $22.11 \pm 0.04$ & $22.81^{\mathrm{a}}$ & & & \\
\hline & Mean & $23.84^{\mathrm{a}}$ & $20.67^{c}$ & $21.73^{\mathrm{b}}$ & & & & \\
\hline \multirow{4}{*}{$\begin{array}{l}\text { Ash } \\
(\%)\end{array}$} & 0 & $2.51 \pm 0.09$ & $2.71 \pm 0.53$ & $2.58 \pm 0.20$ & 2.50 & \multirow{4}{*}{ NS } & \multirow{4}{*}{ NS } & \multirow{4}{*}{ NS } \\
\hline & 15 & $2.38 \pm 0.04$ & $2.42 \pm 0.10$ & $2.50 \pm 0.06$ & 2.46 & & & \\
\hline & 30 & $2.17 \pm 0.15$ & $2.40 \pm 0.26$ & $2.29 \pm 0.05$ & 2.36 & & & \\
\hline & Mean & 2.35 & 2.51 & 2.46 & & & & \\
\hline \multirow{4}{*}{$\begin{array}{l}\text { EE } \\
(\%)\end{array}$} & 0 & $1.93 \pm 0.18$ & $1.65 \pm 0.05$ & $1.90 \pm 0.15$ & $1.83^{\mathrm{a}}$ & \multirow{4}{*}{ NS } & \multirow{4}{*}{$* *$} & \multirow{4}{*}{ NS } \\
\hline & 15 & $1.53 \pm 0.13$ & $1.28 \pm 0.13$ & $1.33 \pm 0.23$ & $1.38^{\mathrm{b}}$ & & & \\
\hline & 30 & $0.75 \pm 0.10$ & $1.15 \pm 0.10$ & $0.65 \pm 0.10$ & $0.85^{c}$ & & & \\
\hline & Mean & 1.40 & 1.36 & 1.29 & & & & \\
\hline
\end{tabular}

$* * p<0.01 ; N S=$ Non-significant $(p>0.05)$; Means with different superscripts within a row or column differ significantly $(p<0.05) . T=$ Treatment, $D=$ Day. 


\section{Results and Discussion}

\section{Proximate analysis}

The proximate composition of different sausages was analyzed in table 2 and highly significant differences were found in dry matter (\%) and crude protein (\%) among different sausages as well as among different storage time. The range of overall observed DM content at different treatments was ranges from 29.15 to $30.33 \%$. Of the three treatments, highest DM content was observed at $T_{2}$. On the other hand, the range of overall observation of different days of intervals of DM content was ranges from 29.30to $30.07 \%$. The DM content increased with the increase in storage period because of moisture loss. Naveena et al. (2008) have reported an increase in storage period with an increase in the dry matter content of pomegranate peel extract and pomegranate rind powder extract, respectively. The range of overall observed $\mathrm{CP}$ content at different treatments was 20.67 to $23.84 \%$. Of the three treatment groups, the highest value was observed in $T_{1}$. The range of overall observed of different days of intervals of $\mathrm{CP}$ content was 21.59 to $22.81 \%$. The CP content was increased with the increase in the storage period. Yadav et al. (2018) and kumar et al. (2013) found that protein content decreased significantly when added wheat bran (WB), dried carrot pomace (DCP) and green banana (GBF), soybean hulls flours (SHF) in chicken sausage respectively.

Ali et al. (2011) found that crude protein, crude fat and total ash content were significantly lower in the group with added rice flour compared with the no flour group. The range of overall observed ash content at different treatments was 2.35 to $2.51 \%$. Of the three treatments, the higher ash content was observed in $T_{2}$ group. Although no significant differences were found, the lowest ash content was observed at $30^{\text {th }}$ day and highest ash content at 0 day. Bhattacharya et al. (2007) while conducting an experiment observed the same trend and they reported that ash content decreased during frozen storage of meat products incorporated with natural herbs. Kaur et al. (2015) prepared chicken sausages incorporated with carrot and reported that with an increase in the storage period ash content is gradually decreased. The range of overall observed $\mathrm{EE}$ content at different treatments was 1.29 to $1.40 \%$. Among three treatment groups, the highest EE content was observed at $T_{1}$ group. The range of overall observed of different days of intervals of EE content was 0.85 to $1.83 \%$. The mean values observed from $0,15^{\text {th }}$ and $30^{\text {th }}$ days of observation indicated that there were significant differences $(p<0.01)$ among these three days of observation. The EE content was decreased with the increase storage period. Ether extract content of the products showed significantly $(p<0.05)$ decreasing trend with increasing levels of incorporation of pumpkin in chicken sausages reported by Zargar (2014). Similar result was found by Alaei et al (2018) that the fat content decreased with the increased levels of inulin substitution in chicken sausages.

\section{Physicochemical properties}

Significant differences were found in cooking loss (\%) among the sausage batters. Significantly higher cooking loss (\%) was found in $\mathrm{T}_{1}(6.67 \%)$, while no significant differences were found between $\mathrm{T}_{2}(4.83 \%)$ and $\mathrm{T}_{3}(4.60 \%)$. From Table 3 the range of overall observed $\mathrm{pH}$ value at different treatments was 6.49 to 6.51 .

Table 3: $\mathrm{pH}$ of low fat broiler meat sausages incorporate with rice and wheat flour during different storage time

\begin{tabular}{|c|c|c|c|c|c|c|c|c|}
\hline \multirow[t]{2}{*}{$\begin{array}{l}\text { Paramet } \\
\text { er }\end{array}$} & \multirow[t]{2}{*}{$\begin{array}{l}\text { Storage } \\
\text { time (D) }\end{array}$} & \multicolumn{4}{|c|}{ Treatments } & \multicolumn{3}{|c|}{$\begin{array}{c}\text { Level of } \\
\text { Significance }\end{array}$} \\
\hline & & $\begin{array}{l}\text { Broiler meat } \\
\left(T_{1}\right)\end{array}$ & $\begin{array}{l}\text { Broiler } \\
\text { meat }+10 \% \\
\text { rice flour }\left(T_{2}\right)\end{array}$ & $\begin{array}{l}\text { Broiler } \\
\text { meat+10\% } \\
\text { wheat } \\
\text { flour }\left(T_{3}\right)\end{array}$ & Mean & $\mathbf{T}$ & D & $T \times D$ \\
\hline \multirow{4}{*}{ pH } & 0 & $6.53 \pm 0.01$ & $6.52 \pm 0.01$ & $6.53 \pm 0.01$ & $6.52^{\mathrm{a}}$ & \multirow{4}{*}{ NS } & \multirow{4}{*}{$* *$} & \multirow{4}{*}{ NS } \\
\hline & 15 & $6.51 \pm 0.01$ & $6.50 \pm 0.01$ & $6.49 \pm 0.01$ & $6.50^{b}$ & & & \\
\hline & 30 & $6.49 \pm 0.01$ & $6.48 \pm 0.01$ & $6.49 \pm 0.01$ & $6.49^{b}$ & & & \\
\hline & Mean & 6.51 & 6.50 & 6.49 & & & & \\
\hline
\end{tabular}

$* * p<0.01 ; N S=$ Non-significant $(p>0.05) ;$ Means with different superscripts within a column differ significantly $(p<0.05)$. T=Treatment, $D=$ Day. 
However, the higher value was observed in $T_{1}$ and the lower value was observed in $T_{3}$. The range of overall observed of different days of intervals of cooked ph was 6.49 to 6.52 . The higher value was observed in 0 day and lower value was observed at $30^{\text {th }}$ day. Mccarthy et al. (2001) and Carpenter et al. (2007) reported no difference in the $\mathrm{pH}$ of control and test antioxidants like grape seed, bearberry and rosemary extracts incorporated raw and cooked pork meat products.

\section{The surface color (CIE $L *, a *, b *)$}

From Table 4 the range of overall observed color score at different treatment for lightness was 64.19 to 66.37. Of the three treatment group highest reading was observed in $\left(T_{1}\right)$. Whereas, the range of different days of interval of overall observation of color score for lightness was 63.44 to 65.98. Ali et al. (2007) found lightness decrease by adding rice flour to duck sausage.On the other hand, the range of overall observed color score at different treatment for redness was 2.42 to 3.08 . The mean values observed from three treatment and three days storage indicates there were a significant difference $(p<0.01)$ found among three treatments and storage time.

\section{Biochemical properties}

From Table 5 the range of overall observed free fatty acid (FFA) value at different treatments was 0.42 to 0.47 . The $T_{1}$, and $T_{2}$ treatment had similar FFA value whereas $T_{3}$ had a different FFA value. On the other hand, the range of overall observed of different days of intervals of FFA was 0.01 to 1.08 which indicates there was a significant $(p<0.01)$ differences among these three days of observation. The FFA value was increased with the increase storage period. Modi et al. (2004) \& Baker et al. (2013) reported similar to my findings.

The observed Peroxide value (POV-meq $/ \mathrm{kg}$ ) is nearly similar in all treatments. But POV was increased with the increased storage period. Das et al. (2011) reported a significant increase in peroxide value of the meat samples during refrigerated storage.

Table 4: International commission on illumination color measurements (CIE*) of low fat broiler meat sausages incorporate with rice and wheat flour at different storage time

\begin{tabular}{|c|c|c|c|c|c|c|c|c|}
\hline \multirow{2}{*}{$\begin{array}{l}\text { Paramet } \\
\text { er }\end{array}$} & \multirow{2}{*}{$\begin{array}{l}\text { Storage } \\
\text { time (D) }\end{array}$} & \multicolumn{4}{|c|}{ Treatments } & \multicolumn{3}{|c|}{ Level of Significance } \\
\hline & & $\begin{array}{l}\text { Broiler meat } \\
\left(T_{1}\right)\end{array}$ & $\begin{array}{l}\text { Broiler } \\
\text { meat+10 } \\
\% \text { rice } \\
\text { flour }\left(\mathrm{T}_{2}\right)\end{array}$ & $\begin{array}{l}\text { Broiler } \\
\text { meat+10\% } \\
\text { wheat } \\
\text { flour }\left(\mathrm{T}_{3}\right)\end{array}$ & Mean & $\mathbf{T}$ & D & $T \times D$ \\
\hline \multirow[t]{4}{*}{$L *$} & 0 & $65.50 \pm 0.29$ & $66.07 \pm 0.03$ & $65.35 \pm 0.06$ & $65.64^{\mathrm{a}}$ & \multirow{4}{*}{ NS } & \multirow{4}{*}{$*$} & \multirow{4}{*}{ NS } \\
\hline & 15 & $65.10 \pm 2.93$ & $62.68 \pm 1.39$ & $62.55 \pm 0.49$ & $63.44^{\mathrm{b}}$ & & & \\
\hline & 30 & $68.53 \pm 0.47$ & $64.76 \pm 0.29$ & $64.67 \pm 0.46$ & $65.98^{\mathrm{a}}$ & & & \\
\hline & Mean & 66.37 & 64.50 & 64.19 & & & & \\
\hline \multirow[t]{4}{*}{ a* } & 0 & $2.27 \pm 0.03$ & $2.60 \pm 0.02$ & $2.62 \pm 0.01$ & $2.49^{b}$ & \multirow{4}{*}{$* *$} & \multirow{4}{*}{ * } & \multirow{4}{*}{$* *$} \\
\hline & 15 & $3.60 \pm 0.11$ & $2.33 \pm 0.41$ & $2.17 \pm 0.13$ & $2.70^{\mathrm{ab}}$ & & & \\
\hline & 30 & $3.38 \pm 0.09$ & $2.84 \pm 0.03$ & $2.47 \pm 0.13$ & $2.89^{a}$ & & & \\
\hline & Mean & $3.08^{\mathrm{a}}$ & $2.59^{b}$ & $2.42^{b}$ & & & & \\
\hline \multirow[t]{4}{*}{$\boldsymbol{b}^{*}$} & 0 & $10.03 \pm 0.37$ & $9.33 \pm 0.16$ & $10.98 \pm 0.24$ & 10.11 & \multirow{4}{*}{$* *$} & \multirow{4}{*}{ NS } & \multirow{4}{*}{ NS } \\
\hline & 15 & $10.21 \pm 0.60$ & $8.57 \pm 0.36$ & $10.03 \pm 0.07$ & 9.60 & & & \\
\hline & 30 & $10.43 \pm 0.01$ & $9.05 \pm 0.21$ & $10.19 \pm 0.41$ & 9.89 & & & \\
\hline & Mean & $10.22^{\mathrm{a}}$ & $8.98^{b}$ & $10.40^{\mathrm{a}}$ & & & & \\
\hline
\end{tabular}

${ }^{*} p<0.05 ; * * p<0.01 ; N S=$ Non-significant $(p>0.05)$; Means with different superscripts within a row or column differ significantly $(p<0.05)$. T=Treatment, $D=$ Day. 
Table 5: Biochemical properties of low fat broiler meat sausages incorporate with rice and wheat flour during different storage time

\begin{tabular}{|c|c|c|c|c|c|c|c|c|}
\hline \multirow{2}{*}{$\begin{array}{l}\text { Parame } \\
\text { ter }\end{array}$} & \multirow{2}{*}{$\begin{array}{l}\text { Storage } \\
\text { time(D) }\end{array}$} & \multicolumn{4}{|c|}{ Treatments } & \multicolumn{3}{|c|}{ Level of Significance } \\
\hline & & $\begin{array}{l}\text { Broiler } \\
\text { meat }\left(T_{1}\right)\end{array}$ & $\begin{array}{c}\text { Broiler } \\
\text { meat+10 } \\
\% \text { rice } \\
\text { flour }\left(\mathrm{T}_{2}\right)\end{array}$ & $\begin{array}{c}\text { Broiler } \\
\text { meat+10\% } \\
\text { wheat } \\
\text { flour }\left(T_{3}\right)\end{array}$ & Mean & $\mathbf{T}$ & D & $T \times D$ \\
\hline \multirow[t]{4}{*}{ FFA } & 0 & $0.01 \pm 0.00$ & $0.01 \pm 0.00$ & $0.02 \pm 0.01$ & $0.01^{\mathrm{c}}$ & \multirow{4}{*}{ NS } & \multirow{4}{*}{$* *$} & \multirow{4}{*}{ NS } \\
\hline & 15 & $0.20 \pm 0.00$ & $0.20 \pm 0.00$ & $0.25 \pm 0.05$ & $0.22^{\mathrm{b}}$ & & & \\
\hline & 30 & $1.05 \pm 0.05$ & $1.05 \pm 0.05$ & $1.15 \pm 0.05$ & $1.08^{\mathrm{a}}$ & & & \\
\hline & Mean & 0.42 & 0.42 & 0.47 & & & & \\
\hline \multirow[t]{4}{*}{ POV } & 0 & $1.52 \pm 0.05$ & $1.62 \pm 0.02$ & $1.57 \pm 0.07$ & $1.57^{b}$ & \multirow{4}{*}{ NS } & \multirow{4}{*}{$* *$} & \multirow{4}{*}{ NS } \\
\hline & 15 & $1.69 \pm 0.02$ & $1.72 \pm 0.02$ & $1.68 \pm 0.05$ & $1.69^{\mathrm{a}}$ & & & \\
\hline & 30 & $1.69 \pm 0.02$ & $1.73 \pm 0.02$ & $1.75 \pm 0.02$ & $1.72^{\mathrm{a}}$ & & & \\
\hline & Mean & 1.63 & 1.68 & 1.67 & & & & \\
\hline \multirow[t]{4}{*}{ TBARS } & 0 & $0.09 \pm 0.01$ & $0.09 \pm 0.01$ & $0.09 \pm 0.01$ & $0.09^{c}$ & \multirow{4}{*}{ NS } & \multirow{4}{*}{$* *$} & \multirow{4}{*}{ NS } \\
\hline & 15 & $0.11 \pm 0.01$ & $0.12 \pm 0.00$ & $0.12 \pm 0.01$ & $0.11^{\mathrm{b}}$ & & & \\
\hline & 30 & $0.13 \pm 0.01$ & $0.13 \pm 0.00$ & $0.13 \pm 0.01$ & $0.13^{\mathrm{a}}$ & & & \\
\hline & Mean & 0.11 & 0.11 & 0.11 & & & & \\
\hline
\end{tabular}

$* p<0.05 ; * * p<0.01 ; N S=$ Non-significant $(p>0.05)$; Means with different superscripts within a row or column differ significantly $(p<0.05) . T=$ Treatment, $D=$ Day.

In all three treatments the TBARS values was similar and it was 0.11 . The range of different days of intervals of TBARS value was 0.09 to 0.13 that indicated there were significant differences $(p<0.01)$. The TBARS values increased significantly $(p<0.01)$ during storage in all treatments. Devatkal et al. (2008) observed that the TBARS value increased during the refrigerated storage in cooked goat meat patties added with different plant extract. Yadav et al. (2018) found a significant increase in TBARS value of control and fiber enriched sausage with an increase in storage period.

\section{Microbiological assessment}

From Table 6 the range of total coliform count was 4.53 to $4.60 \log _{10} \mathrm{cfu} / \mathrm{g}$ in different treatment groups. Of the three treatment groups the total coliform count was highest in the $\mathrm{T}_{2}$ and lowest in $\mathrm{T}_{3}$. The range of overall observed total yeastmold count from the chicken sausage was 5.04 to $5.16\left(\log _{10} \mathrm{cfu} / \mathrm{g}\right)$ at different treatment groups which indicates that there were a significant differences $(p<0.01)$ of TYMC values found among three treatment groups. Of the three treatment groups the TYMC was highest in $T_{1}$ treatment and lowest was found in $T_{3}$. On the other hand, the range of overall observed of different days of intervals of TYMC value was 4.94 to $5.29 \log _{10} \mathrm{CFU} / \mathrm{g}$. The range of overall observed total viable count from the different chicken sausages was 6.60 to $6.78\left(\log _{10} \mathrm{CFU} / \mathrm{g}\right)$. Of the three treatment groups the TVC was highest in $T_{1}$ and lowest in $T_{3}$. The range of overall observed TVC of different days of interval was 6.44 to $6.94 \log _{10} \mathrm{CFU} / \mathrm{g}$. The mean values observed in TCC, TYMC\& TVC from $0,15^{\text {th }}$ and $30^{\text {th }}$ days of observation indicates that there were a significant differences $(p<0.01)$ found among these three days of observation. In all cases highest value was found at $30^{\text {th }}$ days while lowest was noticed at 0 days of observation which was similar to the claim of Sallam et al. (2004). Kumar et al. (2007) observed that chicken patties prepared by replacing spent hen meat with $5 \%$ sorghum flour, $10 \%$ barley flour and $5 \%$ pressed rice flour recorded higher total plate count and psychrophilic count, which increased significantly during storage up to 35 days of storage. 
Rokib et al. (2019) Bang. J. Anim. Sci. 48 (2):99-107

Table 6: Microbial properties of low fat broiler meat sausages incorporate with rice and wheat flour at different storage time

\begin{tabular}{|c|c|c|c|c|c|c|c|c|}
\hline \multirow[t]{2}{*}{ Parameter } & \multirow[t]{2}{*}{$\begin{array}{c}\text { Storage } \\
\text { time (D) }\end{array}$} & \multicolumn{4}{|c|}{ Treatments } & \multicolumn{3}{|c|}{$\begin{array}{c}\text { Level of } \\
\text { Significance }\end{array}$} \\
\hline & & $\begin{array}{l}\text { Broiler meat } \\
\qquad\left(T_{1}\right)\end{array}$ & $\begin{array}{c}\text { Broiler } \\
\text { meat }+10 \% \\
\text { rice flour }\left(T_{2}\right)\end{array}$ & $\begin{array}{c}\text { Broiler } \\
\text { meat+10\% } \\
\text { wheat } \\
\text { flour }\left(\mathrm{T}_{3}\right)\end{array}$ & Mean & $\mathbf{T}$ & D & $T \times D$ \\
\hline \multirow{4}{*}{ TCC } & 0 & $4.27 \pm 0.07$ & $4.35 \pm 0.07$ & $4.20 \pm 0.06$ & $4.27^{c}$ & \multirow{4}{*}{ NS } & \multirow{4}{*}{$* *$} & \multirow{4}{*}{ NS } \\
\hline & 15 & $4.65 \pm 0.07$ & $4.60 \pm 0.08$ & $4.57 \pm 0.06$ & $4.61^{\mathrm{b}}$ & & & \\
\hline & 30 & $4.82 \pm 0.09$ & $4.85 \pm 0.06$ & $4.83 \pm 0.07$ & $4.83^{a}$ & & & \\
\hline & Mean & 4.58 & 4.60 & 4.53 & & & & \\
\hline \multirow{4}{*}{ TYMC } & 0 & $5.00 \pm 0.02$ & $4.95 \pm 0.04$ & $4.88 \pm 0.13$ & $4.94^{c}$ & \multirow{4}{*}{$*$} & \multirow{4}{*}{$* *$} & \multirow{4}{*}{ NS } \\
\hline & 15 & $5.14 \pm 0.04$ & $5.05 \pm 0.05$ & $5.02 \pm 0.03$ & $5.07^{b}$ & & & \\
\hline & 30 & $5.35 \pm 0.01$ & $5.31 \pm 0.02$ & $5.21 \pm 0.02$ & $5.29^{a}$ & & & \\
\hline & Mean & $5.16^{a}$ & $5.10^{\mathrm{ab}}$ & $5.04^{b}$ & & & & \\
\hline \multirow{4}{*}{ TVC } & 0 & $6.55 \pm 0.11$ & $6.48 \pm 0.10$ & $6.30 \pm 0.10$ & $6.44^{c}$ & \multirow{4}{*}{ NS } & \multirow{4}{*}{$* *$} & \multirow{4}{*}{ NS } \\
\hline & 15 & $6.82 \pm 0.08$ & $6.74 \pm 0.08$ & $6.60 \pm 0.10$ & $6.71^{b}$ & & & \\
\hline & 30 & $6.97 \pm 0.07$ & $6.97 \pm 0.07$ & $6.90 \pm 0.07$ & $6.94^{\mathrm{a}}$ & & & \\
\hline & Mean & 6.78 & 6.73 & 6.60 & & & & \\
\hline
\end{tabular}

Note: $*=$ Significant $(p<0.05), * *=$ Highly Significant $(p<0.01), N S=$ Non-significant $(p>0.05) . T=$ Treatment $\mathrm{D}=$ Day

Table 7: Sensory properties of cooked low fat broiler sausages manufactured from broiler meat incorporate with rice and wheat flour during different storage time

\begin{tabular}{|c|c|c|c|c|}
\hline \multirow[t]{2}{*}{ Parameters } & \multicolumn{3}{|c|}{ Treatments } & \multirow{2}{*}{$\begin{array}{l}\text { Level of } \\
\text {-Significance }\end{array}$} \\
\hline & Broiler meat $\left(T_{1}\right)$ & $\begin{array}{l}\text { Broiler meat+10\% } \\
\text { rice flour }\left(T_{2}\right)\end{array}$ & $\begin{array}{l}\text { Broiler meat }+10 \% \\
\text { wheat flour }\left(T_{3}\right)\end{array}$ & \\
\hline Color & $4.28 \pm 0.16$ & $4.18 \pm 0.07$ & $4.20 \pm 0.12$ & NS \\
\hline Flavor & $4.13 \pm 0.13^{b}$ & $4.95 \pm 0.07^{a}$ & $4.78 \pm 0.17^{\mathrm{a}}$ & $* *$ \\
\hline Off-flavor & $1.90 \pm 0.06$ & $1.72 \pm 0.14$ & $1.72 \pm 0.09$ & NS \\
\hline Juiciness & $4.38 \pm 0.12^{b}$ & $5.23 \pm 0.10^{\mathrm{a}}$ & $4.98 \pm 0.14^{\mathrm{a}}$ & $* *$ \\
\hline Tenderness & $4.68 \pm 0.09^{b}$ & $5.30 \pm 0.04^{a}$ & $5.15 \pm 0.06^{a}$ & $* *$ \\
\hline Overall acceptability & $4.77 \pm 0.07$ & $4.97 \pm 0.05$ & $4.88 \pm 0.05$ & NS \\
\hline
\end{tabular}

Note: $* *=$ Highly Significant $(p<0.01)$, NS= Non-significant $(p>0.05)$

\section{Sensory evaluation}

From Table 7 significant $(p<0.01)$ differences were found in flavor, juiciness and tenderness. In all three attributes the highest value was observed in $T_{2}$. This finding is almost similar to the Santhi and Kalaikannan (2014) and Ali et al. (2011).The higher color score was observed in $\left(T_{1}\right)$ and lower value was observed in $\left(T_{2}\right)$ $(p>0.05)$. Although no significant differences were found in color among different sausages 
from sensory evaluation, Syuhairah et al. (2016) reported that the color of sausages varied significantly among samples due to the differences in the original color of extenders. Although no significant differences were found, broiler meat sausage with $10 \%$ rice flour $\left(T_{2}\right)$ has higher acceptability. Ali et al. (2011) found that addition of rice flour increased the overall acceptability of duck sausage to that of pork and chicken sausages.

\section{References}

Ahhmed AM, S Kawahara, K Ohta, K Nakade, T Soeda and M Muguruma (2007). Differentiation in improvements of gel strength in chicken and beef sausages induced by transglutaminase. Meat Science, 76:455-462.

Alaei F, M Hojjatoleslamy and SMD Hashemi (2018). The effect of inulin as a fat substitute on the physicochemical and sensory properties of chicken sausages. Food Science and Nutrition $6(2): 512-519$.

Ali MS, GH Kang, HS Yang, JY Jeong, YH Hwang, GB Park and ST Joo (2007). A comparison of meat characteristics between duck and chicken breast. Asian-Australasian Journal of Animal Science 20:1002-1006.

Ali MS, GD Kim, HW Seo, EY Jung, BW Kim, HS Yang and ST Joo (2011). Possibility of Making Low-fat Sausages from Duck Meat with Addition of Rice Flour. Asian-Australasian Journal of Animal Science 24(3):421 - 428.

AMSA (1995). Research guidelines for cookery, sensory evaluation and instrumental tenderness measurements of fresh meat. Chicago III. American Meat Science Association and Nutritional Livestock and Meat Board. Analytical Chemists international Maryland, USA.

Anna Anandh (2011). Shelf life of boiled restructured buffalo meat rolls in refrigerated storage under vacuum packaging condition. Journal of Applied Animal Research 43:318-323.

AOAC (1995). Official method of analysis of the Association of Official Analytical Chemists $17^{\text {th }}$ edition. Association of Official Analytical Chemists. Washington, DC, 7:65-68.

AOAC (2005). Official methods of analysis (18th edition) Association of official analytical chemist. As a measure of lipid peroxidation. Journal of American oil Chemist Societies 66:813- 817.

Baker IA, JE Alkass and HH Saleh (2013). Reduction of Oxidative Rancidity and Microbial Activities of the Karadi Lamb Patties in Freezing Storage Using Natural Antioxidant Extracts of Rosemary and Ginger. International Journal of Agricultural and Food Research 2:31-42.

Bhattacharya D, M Sinhamahapatra and S Biswas (2007). Preparation of sausage from spent duck

\section{Conclusion}

Rice and wheat flours can be a good source of carbohydrate and replacer of fat in chicken sausage. So, it may be concluded that that low fat chicken sausages can be made with $10 \%$ rice and wheat flour without lowering the overall acceptability.

\section{Conflict of interest}

The author has no conflict of interest to declare.

an acceptability study. International Journal of Food Science and Technology 42:24-29.

Carpenter R, MN O'Grady, YC O'Callaghan, NM O'Brien, JP Kerry (2007). Evaluation of the antioxidant potential of grape seed and bearberry extracts in raw and cooked pork. Journal of meat Science 76:604-610.

Das AK, V Rajkumar and BK Dwivedi (2011). Antioxidant effects of curry leaf (Murrayakoenigii) powder on quality of ground and cooked goat meat. International Journal of Food Science 18:559-565.

Devatkal S, SK Mendiratta and ASR Anjaneyulu (2008). Effect of calcium lactate on the quality and shelf life of restructured pork rolls. Journal of Meat Science 1:1-6.

Gnanasambandam R and JF Zayas (1992). Functionality of wheat germ protein in comminuted meat products as compared with corn germ and soy proteins. Journal of Food Science 57:829-833.

Huang SC, CY Shiau, TE Liu, CL Chu and DF Hwang (2005). Effects of rice bran on sensory and physico-chemical properties of emulsified pork meatballs. Meat Science 70:613-619.

ISO (1995). Recommendation of the meeting of the subcommittee, International Organization for Standardization, on meat and meat products. Iso/tc 36:10-18.

Jung S, YS Bae, HI Yong, HJ Lee, DW Seo, HB Park, $\mathrm{JH}$ Lee and C Jo (2015). Proximate composition, and I-carnitine and betaine contents in meat from Korean indigenous chicken. Asian Australasian Journal of Animal Science 28:1760-1766.

Kaur M, A Kumar, S Kumar, HR Hakeem and S Gupta (2015). Effect of carrot on quality characteristics of chicken sausages. Journal of Indian veterinary science 92:44-47.

Kumar RR, BD Sharma, M Kumar, AK Chidanandaiah and C Biswas (2007). Storage quality and shelf life of vacuum packaged extended chicken patties. Journal of Muscle Foods 18:253-263.

Kumar V, AK Biswas, J Sahoo, MK Chatli and S Sivakumar (2013). Quality and storability of chicken sausages formulated with green banana and soybean hulls flours. Journal of Food Science and Technology 50(6):1058-1068. 
Laureys C (1996). A natural choice for texture: Rice derivatives. Food Technology 3:68-71.

Mccarthy TL, JP Kerry, JF Kerry, PB Lynch and DJ Buckley (2001). Assessment of the antioxidant potential of natural food and plant extracts in fresh and previously frozen pork patties. Journal of meat Science 57:177-184.

Mielnik MB, K Aaby, K Rolfsen, MR Ellekjær and A Nilsson (2002). Quality of comminuted sausages formulated from mechanically deboned poultry meat. Meat Science 61:73-84.

Miller AJ, SA Ockerman and SA Palumbe (1980) Effect of frozen storage on functionality of meat for processing. Journal of Food Science 50:531534

Miller GG and SM Groziak (1996). Impact of fat substitutes on fat intake. Lipids 31:293 -296.

Modi VK, NS Mahendrakar, NM Sachindra and DN Rao (2004). Quality of sausages prepared from fresh fresh and smoked layer chicken meat. Journal of Muscle Foods, 15:195-204.

Naveena BM, AR Sen, S Vaithiyanathan, Y Babji and $N$ Kondaiah (2008). Comparative efficacy of pomegranate juice, pomegranate rind powder extract and BHT as antioxidants in cooked chicken patties. Meat Science 80:1304-1308.

Rukunudin IH, PJ White, CJ Bern and TB Bailey (1998). A modified method for determining free fatty acids from small soybean sample sizes. Journal of American Oil Chemists' Society 75:563-568

Santhi D and A Kalaikannan (2014). The effect of addition of oat flour in low-fat chicken sausages. Journal of Nutritional Food Science 4:1-4.
SAS Institute Inc. (2009). User's Guide: Statistics, Version 9.1. SAS Institude Inc., Cary, NC.

Schmedes A and G Holmer (1989). A new thiobarbituric acid (TBA) method for the determination of storage period of meat products. Journal of Meat Science 70:12-19

Singh P, J Sahoo, MK Chatli and AK Biswas (2014). Shelf life evaluation of raw chicken meat emulsion incorporated with clove powder, ginger and garlic paste as natural preservatives at refrigerated storage $\left(4 \pm 1^{\circ} \mathrm{C}\right)$. International Food Research Journal 21(4):1363-1373.

Syuhairah A, N Huda, ZA Syahariza and A Fazilah (2016). Effects of Vegetable Incorporation on Physical and Sensory Characteristics of Sausages. Asian Journal of Poultry Science 10:117-125.

Wylie-Rosett, J (2002). Fat Substitute and health: An advisory from the nutrition committee of the American Heart Association. Circulation 105:2800-2804.

Yadav S, AK Pathera, RUI Islam, AK Malik and DP Sharma (2018). Effect of wheat bran and dried carrot pomace addition on quality characteristics of chicken sausage. Asian-Australasian Journal of Animal Sciences 10:1-9.

Yang HS, MS Ali, JY Jeong, SH Moon, YH Hwang, GB Park and ST Joo (2009). Properties of duck meat sausages supplemented with cereal flours. Poultry Science Association Inc. 88:1452-1458

Zargar FA, S Kumar, ZF Bhat and P Kumar (2014). Effect of pumpkin on the quality characteristics and storage quality of aerobically packaged chicken sausages. Journal of springer Plus 3:39. 